\title{
PERBEDAAN PENGETAHUAN KADER POSYANDU TENTANG \\ DETEKSI DINI TUMBUH KEMBANG (DDTK) PRA DAN \\ PASCA PENYULUHAN DI POSYANDU \\ (Desa Putukrejo Kecamatan Loceret Kabupaten Nganjuk)
}

Erma Herdyana ${ }^{1}$,Zerin Novitasari ${ }^{2}$

Akademi Kebidanan Dharma Husada Kediri

\begin{abstract}
ABSTRAK
Deteksi Dini Tumbuh Kembang anak adalah upaya penjaringan untuk mengetahui adanya penyimpangan tumbuh kembang bayi dan balita serta untuk mengoreksi adanya faktor resiko. Keberadaan kader sering dikaitkan dengan kelancaran pelayanan kesehatan. Keberadaan kader secara sukarela, ikhlas, mau dan sanggup melaksanakan kegiatan posyandu. Penelitian ini bertujuan untuk menganalisa perbedaan pengetahuan kader posyandu tentang DDTK pra dan pasca penyuluhan di posyandu.

Penelitian ini menggunakan One Group Pre-Post Design dengan penelitian pra-pasca test dalam satu kelompok. Populasi penelitian adalah semua kader posyandu sejumlah 12 responden dengan teknik pengambilan sampling jenuh, sehingga seluruh responden dijadikan sampel. Varibel yang digunakan yaitu variabel independen (penyuluhan kader tentang deteksi dini tumbuh kembang) dan dependen (pengetahuan kader tentang deteksi dini tumbuh kembang). Pengumpulan data menggunakan kuesioner, pengolahan dan editing, coding, scoring, tabulating dan dianalisa dengan uji Wilcoxon.

Hasil penelitian menunjukkan bahwa pra penyuluhan hanya $2(16,7 \%)$ dari 12 responden yang memiliki pengetahuan baik tentang DDTK, sedangkan pasca penyuluhan jumlah responden yang memiliki pengetahuan dengan kategori baik sejumlah 11 responden $(91,7 \%)$ dari 12 responden. Sedangkan hasil uji statistik dengan menggunakan uji wilcoxon, diperoleh hasil nilai $\mathrm{Z}$ sebesar -2.983 dengan tingkat signifikan $(\sigma)$ sebesar $0,000(\sigma \leq 0,05)$.

Kesimpulan hasil penelitian terdapat perbedaan yang signifikan antara pengetahuan kader posyandu tentang DDTK pra dan pasca penyuluhan di Posyandu. Dengan demikian diharapkan kader lebih termotivasi untuk menambah informasi dan pengetahuan tentang DDTK melalui tenaga kesehatan, media massa atau sumber-sumber lain.
\end{abstract}

Kata Kunci : Pengetahuan, DDTK, Kader Posyandu, Penyuluhan 


\section{PENDAHULUAN}

Anak merupakan aset orang tua yang sangat berharga. Pertumbuhan dna perkembangan anak harus dipantau sejak lahir, sehingga orag tua mengetahui adakah penyimpangan tumbuh kembang yang terjadi pada anaknya. Pemantauan tumbuh kembang dapat dilakukan di posyandu. Sasaran utama kegiatan posyandu adalah balita dan orangtuanya, ibu hamil, ibu menyusui, dan bayi. (Cahyo,2010:18)

Perlu dukungan dari masyarakat melalui tersedianya kader posyandu. Kader diharapkan mampu Kesarana kesehatan apabila menemukan anak yang memiliki keterlambatan perkembagan (Depkes RI, 2010).

Periode terpenting dalam tumbuh kembang anak adalah masa balita. Dalam perkembangan anak terdapat masa kritis dimana diperlukan rangsangan atau stimulasi yang berguna agar potensi berkembang, sehingga perlu mendapat perhatian. Menurut Frankerburg (1981) dalam buku Hanum Marimbi (2010 :85), Denver Development Stress Test (DDST) mengemukakan 4 (empat) parameter perkembangan yang dipakai dalam menilai perkembangan anak balita yaitu: personal social (kepribadian/tingkah laku sosial), Fine Motor Adaptive (gerakan motorik halus), Language (bahasa), Gross Motor (perkembangan motorik kasar).

Deteksi dini tumbuh kembang yang dilakukan oleh RSU dr. Soetomo Surabaya pada tanggal 5 Agustus 2007 menemukan dalam 2.634 anak terdapat $14,3 \%$ gizi kurang, gizi baik $(82,1 \%)$, gizi lebih $(3,6 \%)$ untuk deteksi pertumbuhan berat badan. Untuk tinggi badan, perawakan pendek $(13,8 \%)$, menggerakkan, menginformasikan masyarakat untuk melakukan kegiatan yang bersifat sendiri untuk meningkatkan status kesehatan dan kelancaran pelayanan kesehatan. Dari beberapa tugas yang dimiliki kader, salah satunya adalah kesehatan anak yaitu perkembangan anak balita. Dalam perkembangan balita, kader memiliki peranan melakukan penyuluhan pada orang tua (ibu) tentang kesehatan anak, pemantauan dan stimulasi atau rangsangan dini perkembangan serta melaporkan tinggi badan normal sesuai usia $(83,3 \%)$, dan perawakan tinggi $(2,9 \%)$.

Sedangkan lingkar kepala ditemukan micro cephaly $(8,3 \%)$, normal $(90 \%)$ dan macro cephaly $(1,7 \%)$, perkembangan normal sesuai usia $(53 \%)$, meragukan (13\%), penyimpangan perkembangan $34 \%$ yang terdiri dari penyimpangan motorik kasar 10\%, motorik halus $30 \%$, bicara bahasa $40 \%$, sosialisasi kemandirian $\quad 16 \%$. (Fatichatun Nadhiroh, 2007)

Pada kegiatan posyandu untuk penilaian tumbuh kembang dibutuhkan kader yang memiliki pengetahuan berkenaan dengan penilaian tumbuh kembang balita.

Dari studi Pendahuluan diperoleh di Posyandu Desa Putukrejo, Kec. Loceret, kab. Nganjuk dari hasil wawancara tentang DDTK pada 10 kader posyandu, 6 diantaranya belum mengetahui tentang DDTK, mereka mengatakan bahwa tugas mereka dalam posyandu hanya penimbangan $\mathrm{BB}$, pengukutan TB, mengisi buku KIA. Dan memberikan vitamin jika perlu. Dari uraian di atas menunjukkan banyak kader yang belum mengerti 
tentang Deteksi Dini Tumbuh Kembang (DDTK), sehingga perlu diberikan penyuluhan.

\section{METODE}

Rancangan penelitian yang digunakan dalam penelitian ini adalah studi komparatif, untuk mengkaji perbandingan terhadap pengaruh (efek) pada kelompok subjek tanpa adanya suatu perlakuan dari penelitian. Dengan menggunakan metode Pretest-Posttest Design dengan cara melakukan $\mathrm{s}^{\text {nt. }}$ kali pengukuran di depan /pres 9 sebelum adanya perlakuan dan posttest setelah perlakuan. Didapatkan populasi yaitu seluruh kader posyandu di Desa Putuk Rejo Kecamatan Loceret Kabupaten Nganjuk sebanyak 20 orang. Teknik pengambilan sampel dengan Nonprobability Sampling sejumlah 20 responden. Terdapat Sebelum dilakukan penyuluhan, peneliti memberikan leafleat kepada seluruh responden dan memberi kesempatan kepada responden untuk terlebih dahulu membaca leafleat tersebut. Setelah itu dilakukan penyuluhan dan memberikan leafleat kembali pasca penyuluhan.

Untuk mengetahui adanya perbedaan pengetahuan kader posyandu tentang DDTK pra dan pasca penyuluhan dilakukan uji Wilcoxon
Independent Variable yaitu penyuluhan kader tentang deteksi dini tumbuh kembang dan Dependent Variable yaitu pengetahuan kader tentang deteksi dini tumbuh kembang.

Instrumen penelitian ini menggunakan kuesioner. Kuesioner telah melalui tahap uji validitas dan reliabilitas instrumen. Kuesioner berjumlah 20 soal dengan 10 soal denga pernyataan positif dan 10 soal dengan pernyataan negatif yang meliputi pengertian DDTK, jenis DDTK, jadwal DDTK, tujuan DDTK, melaksanaan DDTK.

Analisa data dihitung dengan menggunakan

$$
\mathrm{P}=\frac{x}{y} \times 100 \%
$$

Maka skala yang digunakan adalah sebagai berikut :

Baik : 76\%-100\%

Cukup : $56 \%-75 \%$

Kurang: $<56 \%$

Match Pairs Test. Dengan penghitungan $\mathrm{Z}$ hitung $<\mathrm{Z}$ tabel nilai negatif dan positif maka Ho diterima dan bila $\mathrm{Z}$ hitung $>\mathrm{Z}$ tabel tanpa memperhitungkan nilai negatif positif maka $\mathrm{H} 1$ diterima.

Untuk menjaga etika penelitian dan kerahasiaan responden maka peneliti meminta surat ijin penelitian dan responden mengisi lembar persetujuan untuk menjadi responden.

\section{HASIL}

Jumlah responden yang datang pada waktu penyuluhan adalah 12 responden. Dari hasil pengumpulan data didapatkan mayoritas usia kader $>35$ tahun $(58,3 \%)$, tingkat pendidikan tertinggi yaitu SMP (41,7\%), pekerjaan mayoritas adalah wiraswasta dan IRT (33.3\%), penghasilan paling banyak adalah berkisar Rp. 500.000 sd Rp. $1.000 .0000 \quad(41,7 \%), \quad$ pernah mendapatkan informasi tentang DDTK (75\%), dengan sumber informasi yang 
didapatkan dari petugas kesehatan penyuluhan kepada kader posyandu di $(75 \%)$

Berdasarkan pengetahuan kader posyandu tentang DDTK pra dan pasca

Desa Putukrejo, kecamatan Putukrejo, kabupaten Nganjuk tertera pada tabel 1 sebagai

berikut

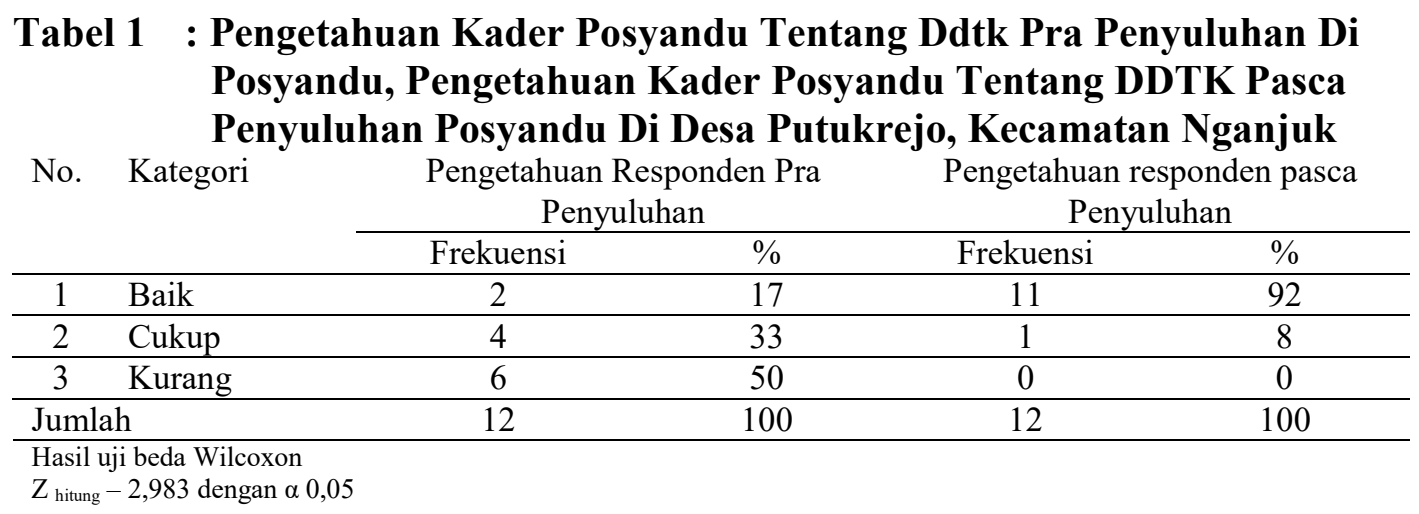

Berdasarkan Tabel 1 : diketahui bahwa pengetahuan kader posyandu tentang DDTK pra penyuluhan mayoritas berpengetahuan kurang yaitu sebanyak 6 responden $(50 \%)$ sedangkan pasca penyuluhan didapatkan sebanyak 11 responden (92\%). Berdasarkan hasil uji statistik

\section{DISKUSI}

Berdasarkan hasil penelitian yang dilakukan pada 12 responden untuk mengidentifikasi pengetahuan Kader Posyandu tentang DDTK pra penyuluhan di posyandu didapatkan hasil $50 \%$ berpengetahuan kurang tentang DDTK. Dari total 12 responden hanya 2 responden yang mengetahui tentang tujuan DDTK. Faktor yang turut berperan dalam pengetahuan responden adalah usia. Menurut Hunclok (1998) semakin cukup umur, tingkat kematangan dan kekuatan seseorang akan lebih matang dalam berfikir dan bekerja. Dari segi kepercayaan masyarakat seseorang yang lebih dewasa menggunakan Wilcoxon Match Pair Test menunjukkan $\mathrm{Z}$ sebesar -2,983 dengan tingkat signifikansi $(\sigma)$ sebesar $0.000(\sigma \leq 0,05)$, maka $\mathrm{H}_{0}$ ditolak dan $\mathrm{H}_{1}$ diterima yang artinya ada perbedaan pengetahuan kader posyandu tentang DDTK pra dan pasca penyuluhan di posyandu. dipercayai dari orang yang belum tinggi kedewasaannya. Hal ini kan sebagian dari pengalaman dan kematangan jiwa. (Wawan, 2010:17) Seseorang kan memperoleh pengetahuan dari hasil inderanya akan tetapi setiap orang memiliki daya ingat dan daya tangkap yang berbeda-beda. Namun, terdapat kemungkinan lain yaitu adanya pemahaman masyarakat yang kurang tepat mengenai DDTK. Terdapat bebrapa bias yang memungkinkan responden menjawab benar yaitu kuesioner yang bersifat tertutup, dikarenakan banyak faktor seperti kemampuan dalam menganalisa soal, 
ketelitian dalam menjawab pertanyaan, memang benar-benar mengetahui materi atau bahkan karena faktor keberuntungan. Latar belakang pendidikan juga berpengaruh terhadap pengetahuan. Pendidikan dapat mempengaruhi seseorang termasuk juga perilaku seseorang akan pola hidup teritama dalam motivasi untuk sikap berperan serta dalam pembangunan kesehatan. (Wawan, 2010 : 17). Informasi merupakan sumber utama dalam meningkatkan pengetahuan (Notoadmodjo, 2003: 15) Informasi yang diperoleh responden mempengaruhi pengetahuan khususnya DDTK. Sumber informasi terbanyak tentang DDTK diperoleh dari petugas kesehatan yaitu sejumlah 9 responden $(75 \%)$ dengan kriteria pengetahuan kurang sebelum diberi penyuluhan. Adapun pekerjaan menurut Markum (1991) dalam Eko Agus (2009), manusia memerlukan suatu pekerjaan untuk dapat berkembang dan berubah. Oleh sebab itu pekerjaan juga merupakan faktor yang mempengaruhi pengetahuan seseorang.

Pengetahuan kader tentang DDTK pasca penyuluhan di Posyandu Desa Putukrejo Kecamatan Loceret Kabupaten Nganjuk mengalami peningkatan yaitu 11 responden $(91,7 \%)$ berpengetahuan baik dan 1 responden $(8,3 \%)$ responden berpengetahuan cukup. Tidak ada responden yang memiliki pengetahuan kurang. Tujuan DDTK dapat diterima dengan baik hal ini berdasarkan perolehan nilai yang cukup signifikan yaitu 11 responden dapat menjawab dengan benar pada tujuan DDTK yang semula hanya 2 responden saja yang menjawab benar.

Penyuluhan dilakukan dengan metode ceramah dan tanya jawab. Pengetahuan yang baik pada kader posyandu pasca penyuluhan tentang Deteksi Dini Tumbuh Kembang (DDTK) menunukkan keberhasilan dalam penyuluhan. Informasi merupakan sumber utama dalam meningkatkan pengetahuan. Sesuai dengan pendapat Notoadmodjo (2003 : 15) yaitu untuk meningkatkan pengetahuan dipengaruhi oleh beberapa faktor pemberian informasi.

Terdapat perbedaan pengetahuan kader posyandu tentang DDTK pra dan pasca penyuluhan di Posyandu Desa Putukrejo Kecamatan Loceret Kabupaten Nganjuk yang signifikan.

Peningkatan pengetahuan kader posyandu tentang DDTK pra dan pasca penyuluhan dipengaruhi oleh faktor internal seperti tingkat pendidikan dan informasi, juga disebabkan oleh faktor pengalaman dimana sebagian besar responden mampu menyerap informasi yang mereka dapatkan dengan baik. Pengalaman dapat digunakan sebagai upaya memperoleh pengetahuan dengan cara mengulang kembali pengalaman yang pernah diperoleh dalam memecahkan masalah yang dihadapi di masa lalu. (Wawan 2010 :15)

Pengetahuan akan berkembang seiring dengan bertambahnya usia dan tututan hidup seseorang. Sehingga pengetahuan yang diperoleh dari proses pendidikan yang dimulai sejak lahir, baik formal maupun non formal akan sangat menentukan seseorang dalam 
menghadapi lingkungan. Pengetahuan juga merupakan domain yang sangat penting untuk terbentuknya sikap dan perilaku. (Notoadmodjo, 2007:63)

Perubahan perilaku yang dimaksudkan pada kesediaan untuk menerapkan / menggunakan motivasi

\section{DAFTAR PUSTAKA}

Anik Maryunani. 2010. Ilmu Kesehatan Anak Dalam Kebidanan. Jakarta : TIM

Arikunto,Suharsimi. 2006. Prosedur Penelitian Suatu Pendekatan Praktik. Jakarta : Rineka Cipta

Aziz Alimul. 2012. Metode Penelitia Kebidanan dan Teknik Analisis Data. Jakarta : Salemba Medika

Cahyo Ismawati S., dkk. 2010. Posyandu dan Desa Siaga. Jogjakarta : Nuha Medika

Depkes RI. 2005. Pedoman Pelaksanaan Stimulasi, Deteksi dan Intervensi Dini Tumbuh Kembang Anak di Tingkat Pelayanan Dasar

Hanum Marimbi. 2010. Tumbuh Kembang, Status Gizi dan Imunisasi Dasar Pada Balita. Yogyakarta : Nuha Medika

IDAI. Deteksi Dini Tanda dan gejala Penyimpangan Pertumbuhan dan Perkembangan Anak

Maulana, Heri, DJ. 2009. Promosi Kesehatan. Jakarta : EGC yang ditawarkan tetapi yang lebih penting adalah kesediaannya untuk terus belajar. Dengan demikian pemberian penyuluhan mampu mengarahkan kader posyandu pada hal-hal yang positif dalam mengatasi permasalahan tentang DDTK.

Notoadmodjo, Soekidjo. 2005. Metodologi Penelitian Kesehatan. Jakarta : Rieneka Cipta

Nursalam, Rekawati, Sri Utami. 2005. Asuhan Keperawatan Bayi dan Anak 9untuk perawat dan bidan). Jakarta : Salemba Medika

Nursalam. 2011. Konsep dan Penerapan Metodologi Penelitian Ilmu Keperawatan. Jakarta : Salemba Medika.

Rita Yulifah. 2009. Auhan Kebidanan Komunitas. Jakarta : Salemba Medika

Soetjiningsih. 2013. Tumbuh Kembang Anak Edisi 2. Jakarta : EGC

Sugiono. 2005. Metode Penelitian Administrasi. Jakarta : CV Alfabeta Wawan \& Dewi M. 2010. Teori Pengukuran Pengetahuan, Sikap, dan Perilaku Manusia. Yogyakarta: Nuha Medika 